\title{
The Management and Implementation of Human Rights Education in the Primary Schools of Lesotho
}

\author{
Retselisitsoe M. Matheolane \\ Dr. Alfred Henry Makura \\ Central University of Technology, Department of Postgraduate Studies: Education, \\ P. Bag X20539, Bloemfontein, South Africa. \\ Email: amakura@cut.ac.za
}

Doi:10.5901/mjss.2014.v5n11p131

\section{Abstract}

Lesotho, being a signatory to international treaties, has a mandate to ensure that the contents of these treaties are up-held by its citizens. This necessitates the formulation of local laws in line with the international conventions. Education is very important in this case to ensure that citizens understand and abide by these laws. The purpose of this study was to find out if primary school teachers were conversant with international and local laws that protect children and how this knowledge (or lack of) impacts their practice in human rights education. To achieve this, 88 teachers responded to a questionnaire consisting of both closed and open ended items. The results of this study revealed that though teachers could not name international and local instruments that address children rights, they are aware of some rights such as right to education and right to be protected from abuse. Teachers do not only use this knowledge to advocate for children's protection but they also appropriately seek help when children's rights that they are aware of are violated.

Keywords: human rights, education, corporal punishment, management, Lesotho,

\section{Introduction}

Different people define "child" differently. This paper will take a child to be any human being aged eighteen years and below. This description is adapted because it is in line with the definition given by the African Charter on the Rights and Welfare of the child as well as the Lesotho Child Protection and Welfare Act of 2011. The paper argues that upholding children rights from a child's formative years increases one's consciousness and such rights may not be violated in later life. We also argue that it is imperative for academics to be sensitised on the need to uphold such rights in our respective education systems. Using Lesotho as a case in point, we report on how it has managed it's of children's human rights issues particularly in the education system. It is lesson that higher education needs to learn.

\subsection{The Lesotho and African children's rights scenario}

Lesotho is a signatory to the human rights instruments such as the Universal Declaration of Human Rights, Convention on the Rights of a Child (CRC) and the African Charter on the Rights and welfare of the child (the Charter). These international instruments are meant to protect all humans against all forms of abuse and violence with children taking preference in the CRC and the Charter. The Universal Declaration of Human rights is meant to protect the fundamental respect of all human beings (UN 2001). It acknowledges the basic human rights such as the right to life, liberty, right to education and many more. The CRC protects the civil rights of children by providing comprehensive minimum standards that recognise and protect the dignity of children (Shmueli 2008). Children's rights are formulated along human rights, but they specifically address children's special needs to ensure their well-being and development (UNICEF 2004). CRC is sub-divided into three parts. Part I is made up of forty-one articles which specify children's rights, part II, which consist of four articles, specifies issues on the establishment of the Committee on the Rights of the Child and part III, which consist of nine articles, focuses on the guidelines of the CRC.

Article 19 (1) of CRC states that all state parties should take necessary , measures to protect children from all forms of abuse, while in the hands of the parents, legal guardians and any other person who is taking care of the child. It is because of that article that member states enacted laws to protect children. Support to parents, guardians and teachers 
can be provided through law reforms and introduction of education programmes that address issues of children's rights. Education programmes would be aimed at changing people's attitudes so that they are in line with the principles of CRC (Odongo 2004).

Article 42 states that all state parties pledge to actively take appropriate measures to ensure that values and requirements of the convention are well known by both adults and children. Pledging to ensure that the principles of CRC are widely known is important because it enables people to be conversant with the convention so that they can consciously abide by it. Enacting laws is of little importance if such cannot be made public.

The African Charter on the Rights and welfare of the child on the other hand, was adopted by the Organisation of African Unity (OAU), now called the African Unity (AU) in 1990 and was brought into function in 1999 (Olowu 2002). It was drafted on the principles of CRC with the aim of "identifying and prioritising issues specifically affecting African children in addition to globally recognised and generally applicable principles" (Njungwe 2009:12). After studying the $\mathrm{CRC}$, African leaders found that the instrument was devoid of issues affecting the African child hence decided to supplement the global document (Kaime 2009). Unique issues that needed to be addressed to protect children in the African context included apartheid, armed conflicts, socio-economic, cultural and developmental circumstances. These factors put children in situations which demand special care and protection and may put children at risk of not realizing their inherent human rights if they are not addressed (OAU 1999). For example the charter prohibits recruitment of children to be soldiers. Moreover, marriage or engagement of children is also prohibited (Olowu 2002). Furthermore, the charter facilitates children's rights discourses within the African context by providing a context through which children's rights are discussed in Africa (Chirwa 2002).

\subsection{Importance of Human rights education}

The African Charter on the Rights and welfare of the child places a high premium on children's' views. This empowers children to be participants than spectators in the provision and safeguarding of their rights. It enables them to have a platform to influence the provision of their rights (Olowu 2002). It also necessitates the creation and provision of forums where children can talk about their needs and how their rights are violated. To empower children in all these areas, school curriculum should include the contents of the African Charter on the Rights and Welfare of the Child so that children can be social agents for their rights and also be able to assert them whenever need arises (Chirwa 2002; Lloyd 2002; Lloyd 2004). Article 16 of African Charter on the Rights and Welfare of the Child states that "state parties shall take specific legislative, administrative, social and educational measures to protect the child from all forms of torture, inhumane or degrading treatment" (OAU 1999:2). The importance of educational measures in making the African Charter on the Rights and welfare of the child and relevant legal changes known cannot be over-estimated as it promotes the charter to concerned government officials and the general public with the aim of making it well known. Introducing human rights education in schools is one way of making rights widely known in a country. According to Lansdown (1999) human rights education does not only imply including it in the curriculum but it also denotes including issues of rights in the school philosophy so that they guide daily activities of the school.

\subsection{Implications of Human rights education}

Being a signatory to international human rights instruments implies that the government of Lesotho has to take all legal and educational measures to ensure that the rights of children are upheld. To achieve this important obligation the government of Lesotho enacted laws on the basis of Universal Declaration of Human rights, the CRC and the African Charter on the Rights and welfare of the child. The enacted laws include the Education Act of 2010 and the Child Protection and Welfare Act of 2011. The Education Act 2010 (4) states that a learner shall not be subjected to cruel, inhumane and degrading punishment. It also gives parents the responsibility of being involved in the development of the school's disciplinary procedures (Lesotho Government Gazette Extraordinary 2010). The Child Protection and Welfare Act of 2011 is a comprehensive instrument that regulates all issues related to children's life. For example, it specifies the rights of the child and the responsibility of the parents and the state, the protection of children's property, fosterage and adoption of children as well as the trafficking and abduction of the child (Lesotho Government Gazette Extraordinary 2011).

Enacting laws and formulating policies is of little importance if they cannot be used by the citizens of a country. Studies have shown that while international and continental covenants such as CRC and the Charter protect children from all forms of abuse a lot of problems are experienced at the national and local levels (Kaime 2009; Lansdown 1999). For instance, Kaime (2009) found that most states ratify the instruments and pass appropriate legislations but in practice, 
the dynamics of the legislations are not easy to implement. Lansdown (1999) reiterates that millions of children who are of school going age in African are still not in schools and a large number of learners who are admitted into the schools do not complete their basic programme.

\section{The Purpose of the Study}

The purpose of this article is twofold; to explore the Lesotho teachers' knowledge of international and local tools meant to protect school children. Secondly, the study aims to find out how such knowledge is used to benefit learners according to the teachers.

\subsection{Research Questions}

This study will answer the following research questions

1. Are primary school teachers conversant with issues regarding the protection of children's rights and

2. How does knowledge on Human Rights in education (or lack of it) affect teachers' practices?

\section{Methodology}

\subsection{Paradigm}

The philosophical underpinning of this study was post-positivism. As Nieuwenhuis (2007) espouses, post-positivism combines quantification with provision of subjective meaning of a phenomenon. This allows a researcher to use quantitative and qualitative methods of data collection; hence this study used closed and open items to allow creation of descriptive statistics and deeper explanation of ideas.

\subsection{Population}

The population denotes the people who possess certain characteristics which help the researcher to respond to the problem statement of the study (Lapan, Quartaroli \& Riemer 2012). For this study, the population consisted of all the teachers who are currently teaching grades five to seven in some of the primary schools of Lesotho. This population is relevant in this study because human rights education is taught from grade five to seven in Lesotho.

\subsection{Sampling and sampling techniques}

A purposive sample of hundred participants was drawn to respond to a researcher designed questionnaire. Of these, eighty-eight (88) participants returned usable questionnaires. Purposive sampling was used to select teachers who were teaching grades five to seven or had previously taught those grades to participate in this study. According to Bryman (2012) purposive sampling allows researchers to select participants who have insights on the phenomenon. The participants in this study were chosen because Human Rights Education is only done by learners from grade five to seven in the primary schools of Lesotho therefore teachers who taught these grades have information related to human rights education in Lesotho.

\subsection{Instruments}

The data in this study was collected using a self- developed questionnaire. The questionnaire consisted of closed and open ended questions. As Babbie and Mouton (2008) put it, in closed ended questions, the participant has to choose an option from the given answers. In this study, level measurements items which have only two options were used as well as ordinal level items which give participants a chance to choose one answer from four to five options (Bryman 2012). Openended items, where participants are allowed to write their own answers were aimed at obtaining information on teachers' activities concerning Human Rights Education in schools (Babbie \& Mouton 2008). 


\subsection{Pilot testing}

The instrument was piloted among the participants. It was also given to experts to chech on its content quality. Piloting it allowed the researchers to check if the questions were understandable and that the data collection data process was not impeded as well as to check if the language was clear (Bryman 2012). All necessary changes were implemented after piloting the instrument.

\subsection{Data collection procedure}

The collection of data was done by distributing the questionnaires to the participants who wrote answers on the space provided.

\subsection{Ethical issues}

The researcher explained the purpose of the study to the participants and then asked them to voluntarily participate in the study. The researcher assured the participants that their identity would remain confidential and that the data collected will be used for academic purposes only.

\subsection{Data analysis technique}

The closed items were analysed using simple frequencies. The semi structured items were structured and analysed thematically to guide in the analysis. Thematic analysis thus allowed such themes, and sub-themes that emerged during data the study to be analysed clearly (Bryman 2012).

\section{Results}

Eighty-eight teachers participated in the study. All the participants were trained teachers, who held a Diploma in Education (primary). The participants consisted of six principals, three deputy principals and seventy nine teachers as shown in Table 1 below. All the participants had a teaching experience which ranged from two to twenty years.

\subsection{Are teachers conversant with issues on children protection?}

A question was posed to establish if teachers were conversant with laws and conventions on children's rights. All the teachers confirmed being knowledgeable about international instruments that protect children. Initially a teasing question requested the participants to list any human rights they knew. Disturbingly, some participants did not prioritise education human rights among rights. In this regard, only $36.4 \%$ mentioned the right to education. In pursuit of this theme, the majority of the participants (57\%) said that they knew international human rights laws while $43 \%$ said that they are not aware of such instruments. Shockingly, when asked to list any them, only six participants mentioned the United Nation's Convention on the Rights of the Child and only two respondents mentioned the African Charter on the Rights and Welfare of the Child. One of the participants said 'CGPU is one of the international instruments'. Participants were also asked if they knew local laws that protect children's rights and $73.9 \%$ said that they were familiar with such laws while $26.1 \%$ said they were not acquainted with such laws. Only 9.1\% indicated that they knew the Lesotho Education Act of 2010, $4.5 \%$ declared that they knew the Lesotho Child Protection and Welfare Act of 2011.

On the theme focusing on prior learning, all respondents concurred that they had prior (but accidental) exposure on Human Rights Education during their pre-service training. They did Human Rights as a topic in a course called Social and Development Studies, and not as a course on its own. Twenty two comma seven percent (22.7\%) of the participants said they actually had an opportunity of attending in-service training on Human rights Education organised by the Ministry of Education and Training and non- governmental organisations such as World Vision and Roman Catholic Church. Asked the extent they felt confident in teaching after acquiring some basic knowledge on Human Rights Education during their training only thirty-three participants (37.5\%) felt confident, 27 (30.7\%) were familiar with Human Rights knowledge though less confident on teaching the subject. The remainder were neutral.

Participants were also asked how they were managing instructional activities related to Human rights advocacy in their schools in line with international norms and standards. On this aspect, all participants said that they teach Human Rights as a topic in the Social Studies from grades five to seven. It was their considered opinion that this was an indirect 
way of doing advocacy. Teaching Human Rights as part of the subject in the primary school is a norm set during teachers' training at the Lesotho College of Education (LEC), where Human Rights Education was also a topic in a course. In teaching and managing Human rights issues the teachers encountered several challenges that impeded their efforts. The majority of the participants (63.6\%) said that they do not have any problems with teaching about Human Rights. The remainder (36.4\%) said they had challenges. Thus the majority of the participants said that they do not encounter barriers when teaching Human Rights. One respondent said 'having enough information in the students' book and teachers' guide and this makes it easy for learners to understand the content".

Secondly, because teachers learnt about issues of Human Rights at college, they have the necessary skills to tackle the topic. A respondent remarked "human rights are now common and children are open to talk about issues that bother them". Challenges were reported during teaching though. Respondents said that some parents, especially in the rural areas claim that Human Rights contradict the norms of the Basotho. For example, Basotho expect children not to respond or explain themselves when being reprimanded yet children have a right to say their views. A challenge posed by culture is a situation where orphans that did not report when their rights are violated. The cultural environment makes children not to be assertive enough to stand for their rights. To mitigate these challenges, $36.4 \%$ of the respondents submitted that they need training in some areas of Human rights such as the responsibilities that correspond with rights, children's rights, appropriate teaching methods as well as ways of making Human Rights to impact on the parents.

\subsection{Knowledge on Human Rights in education and teachers' practices}

On the question or theme of specific practices done in their schools in implementing the laws that promote the protection of children, the teachers concurred on the need to ensure that children attend school. Most teachers said that they always managed this aspect by making follow ups on learners who are not regular at school and provide necessary support to ensure that such learners are regular at school. For example some teachers said that they talk to parents explaining how withdrawing their children from school is a violation of the children's rights. Campaigns done on "Education for All day" and on parents' meetings are also important in raising awareness about children's rights and local laws that protect children. Teachers were asked to highlight acts of violation of learners' rights they observed or heard during their line of duty. On this issue a striking $90.9 \%$ of the participants reported that they have identified learners whose rights were being violated. The most common form of child abuse identified by teachers is that children are denied their right to education by parents. The participants said that learners were unable to attend school properly because their parents or guardians instruct them to attend to household chores. This included herding animals which was done by boys, and looking after siblings and the sick for girls. Some teachers mitigated this situation by talking to parents, showing them the importance of allowing children to attend school and how making learners drop out of school is the violation of rights.

The second most common violation of children's rights as observed by the participants is sexual abuse perpetrated by people well known to the children such as relatives. Teachers supported learners who had been sexually abused by reporting its occurrence to the police and taking the child to the hospital. Child neglect was also reported by the participants. Some parents do not ensure that their children are well fed and clean. Teachers help such children by reporting the cases to Child and Gender Protection Unit (CGPU), sourcing donations or supporting the children in any way they can. Severe corporal punishment was also mentioned though it was not very common. The last question under this theme sought teachers' knowledge on good practices taking place within the school system. The respondents opined that good school practice in human rights mainly consisted of awareness rising about human rights. Awareness raising campaigns included telling children about their rights in class and at the assembly, as well as addressing the community on human rights on education or human rights day. Besides awareness rising, participants reported that they source out students whose attendance was erratic. Sourcing out learners resulted in reduced absenteeism because parents would be aware that education is one of children's rights. Children who did not attend school included those who are disabled. A perplexing revelation is the notion that the discontinuation of corporal punishment (while it's a child's human right) contributed to misbehaviour. Nevertheless, participants agreed that ceasing corporal punishment was an important management practice in upholding human rights in schools. Some respondents were against the practice of instituting severe corporal punishment, preferring the mild form of corporal punishment instead. Having human rights issues in the school policy as well as school rules and regulations was also mentioned to be a good management practice in upholding human rights.

\section{Discussion}

Data herein showed that all participants were trained teachers with a Diploma in Education (Primary). This exposed them 
to some training on Human Rights Education. Training on Human Rights Education is very important because it equips teachers with necessary skills to tackle this subject in the classroom. The majority of the participants reported that they were aware of international and some local laws that address children's rights. Results revealed that $43 \%$ of the participants were not aware of such instruments. This scenario was further aggravated by the fact that only six teachers out of eighty-eight could mention the UNCRC while only two could mention the CRWC. This shows that the majority of teachers are not conversant with the names of international instruments that aim to protect children. This lack of information gives an impression that teachers are likely to misinterpret the rights and local laws which are put in place in the spirit of these international laws. As the Black and Ethnic Minority Infrastructure in Scotland (BEMIS 2013) organisation asserts, inadequate knowledge on human rights instruments is a barrier to successful human rights education implementation. In the same breath, teachers unacquainted with the local laws that protect children because only $9.1 \%$ and $4.5 \%$ of the participants could correctly mention the Education Act of 2010 and the Child Protection and Welfare Act of 2011, respectively, compared to $73.9 \%$ that claimed to be aware of these laws. Being conversant with the right to education was also reflected in the teachers' practice at school where teachers advocate for children's right to education in different ways. For example, teachers said that they always talked to parents who withdrew their children from school, showing them how such an act is a violation of children's rights.

The results of this study also showed that teachers taught Human Rights as a topic in their respective classes. As such, they perceived themselves as advocates of human rights. Through lesson delivery, teachers were able to manage and implement human rights education. The teachers focussed on such an awareness strategy because lessons in the classrooms seem to focus on what human rights are. Parents were also made aware that dissuading children to attend school was a breach of children's rights. Though the aim of raising awareness is to make the children speak out when they feel like their rights are violated, the way they are taught does not seem to be equipping learners with skills necessary to be assertive about their rights. Participants declared that they were confident in handling and managing Human Rights Education. A minority was not confident. This gives the impression that the majority of teachers are able to convert their knowledge into a productive Human Rights Education in the classroom. This finding is in line with the findings revealed in an Ireland study where it was common for teachers to have inadequate knowledge about human rights instruments (BEMIS 2013).

Regrettably results showed that teachers were aware of human rights violations on their students. Human rights violation prevalence was generally perceived as high, as observed by some teachers, with some of the cases occurring at school and home. The most common form of child abuse identified by teachers is when children were denied their right to education by parents. Some parents and guardians deny their children the opportunity to attend school. Some children are generally absent from school or even drop out because of household chores such as looking after animals, nursing sick parents or minding younger siblings. Previous studies in Lesotho (Kimane 2005) show that orphans were the most vulnerable through being denied access to an education.

Sexual abuse was also found to be prevailing, with girls being the preferred victims. Only a few cases of children's rights breach were reported at school (though corporal punishment was perceived as a norm). The participants said that some teachers were fond of physically punishing the victims. Teachers helped learners by raising awareness among parents. Parents were constantly encouraged to allow leaners to attend school, as anything contrary to this was a breach of their human rights. This suggests that the human rights education approach taken by primary school teachers is a value and awareness model which focuses on the history and importance of human rights (BEMIS 2013). It is however encouraging to note that teachers did not ignore cases of breaches and violations of human rights. Their practice seem to be in line with a former secretary of the United Nations who once said that human rights education does not only mean including human rights issues in the curriculum but it also includes furnishing learners with necessary skills for secure and dignified lives (Human Rights Watch 2011). However Lesotho schools seemed to be lacking in making human rights a spring board for school activities that encapsulated a human rights philosophy and promoted best educational practices.

\section{Conclusions}

This study concluded that teachers are not conversant with international and national laws which protect children despite having studied human rights education during pre-service era. Some teachers reportedly attended in-service training on the human rights subject. While teachers were aware of the existence of International Children's rights conventions, the majority of the teachers could not cite these. A large were percentage of the participants were familiar with local children rights laws. During their lesson delivery, children addressed children's rights issues. They thus perceived themselves as human rights advocates, albeit by default. The participants reported the prevalence of leaner or child abuse violations in schools and in children's homes. The rigid culture of the Basotho, parents' lack of knowledge on human rights and 
teachers' own inadequacies were cited as barriers to the promotion of human rights advocacy. Thus, implementing the human right education agenda in schools was no mean task. It also denies learners from fully enjoying their rights. For example, teachers know that children have a right to education and that that they should be protected from any form of abuse.

\section{Recommendations}

Stemming from the results herein, we recommend that Human rights issues be fused within the school curricula. The conventional approach is wherein Human rights issues are housed in a particular subject. Secondly, higher education institutions those churn out teachers should also assist in the same manner. Such approach, require deliberate and conscious effort to recurriculate. Academic development centres in universities could of necessity work with relevant departments with view to participate in imparting knowledge and practices that seek to improve school practices. Regarding in-service training, the general practice is whereby donor agencies take the lead in training teachers on matters such as human rights. It is imperative that such efforts be spread in such a manner that governments take the lead in imparting a human rights in education philosophy that takes into account the objective contexts of a country. Finally, there is need to tap into and enhance teachers' basic knowledge on local and international instruments that address children's rights. It is our considered opinion that such strategies could go a long way in addressing issues regarding children's rights management and implementation.

\section{References}

Babbie, E. \& Mouton, J.2008. The practice of social research. Cape Town: Oxford University Press.

BEMIS. 2013. A review of human rights Education in schools in Scotland. Retrieved 23rd January 2014 from http://www.bemis.org.uk/documents

Bryman, A. 2012. Social research methods. New York: Oxford University Press

Chirwa, D.M. 2002. The merits and demerits of the African Charter on the Rights and Welfare of the Chid. International Journal of Children's Rights, 10, 157-177

Human Rights Watch. 2011. HRW student task force human rights survey. Downloaded from www.hrwstf.org on the 23rd January 2014

Kimane, I. 2005.Protecting orphaned children through legislation: the case of Lesotho. A paper presented at the $4^{\text {th }}$ World Congress on family law and children's rights. $23^{\text {rd }}$ to $25^{\text {th }}$ March 2005. Cape Town.

Lansdown, G. 1999.Progress in implementing the Convention on the Right of the Child: Factors helping and hindering that process. Prospects 29 (2)

Lapan, S., Quartaroli, M. T. \& Riemer, F.J. (Eds). 2012. Qualitative research: An introduction to methods and design. San Francisco: John Wiley \& Sons.

Lesotho Government Gazette Extraordinary. 2010.Education Act of 2010. Maseru: Government printers

Lesotho Government Gazette Extraordinary. 2011. Child Protection and Welfare Act of 2011. Maseru Government Printers

Lloyd, A. 2004. How to guarantee credence: Recommendation and proposals for the African Committee of experts on the Rights and Welfare of the child. The international Journal of Children's Rights. 12, 21-40.

Lloyd, A. (2002). Evaluation of the African Charter on the Rights and Welfare of the Child and the African Committee of Experts: Raising the gauntlet. The international Journal of Children's Rights. 10, 179-198.

Nieuwenhuis, J. 2007. . Maree, K. (ed) In First steps in research. Pretoria: Van Schaik Publishers

Njungwe, E.N. 2009. International protection of children's rights: An analysis of the African attributes in the African Charter on the Rights and Welfare of the child. Cameroon Journal on Democracy and Human Rights. 3 (1), 4-25.

Odongo, D.O. 2004. The domestication of international standards on the rights of the child: A critical and comparative of the Kenyan example. International Journal of Children's Rights. 12 , 419-430.

Olowu, D. 2002. Protecting children's rights in Africa: A critique of the African Charter on the Rights and Welfare of the Child. International Journal of Children's Rights. 10, 127-136.

Shmueli, B. 2008. The influence of the UN Convention on the rights of the child on corporal punishment-A comparative look. Retrieved on 19 September 2013 from http://law.uoregon.edu/org/oril/docs/10-1/Shmueli.pdf

Organisation of African Unity. 1999. African Charter on the rights and welfare of the child. Addis Abba: Organisation of African Unity.

UN press release (2001). Committee on the Rights of the Child. 686 th meeting. Geneva.

www.un.org/en/documents/udhr accesses 27th January 2014

UNICEF. (2004). The state of the world's children 2005: Children under threat. New York: UNICEF. 
